\title{
Antisickling and Antibacterial Activities of Anthocleista schweinfurthii Gilg. (Gentianaceae) from Non-human Primates Pharmacopoeia in Democratic Republic of the Congo
}

\author{
Samy Ngunde-te-Ngunde ${ }^{1,2}$, Emmanuel Moke Lengbiye ${ }^{2}$, Tshidibi Dipa Joseph ${ }^{2}$, Kengo \\ Valentia Franck ${ }^{1}$, Ruphin D. Djolu ${ }^{3}$, Colette Ashande Masengo ${ }^{3}$, Benjamin Z. Gbolo ${ }^{3}$, \\ Iteku Bekomo Jeff ${ }^{1,2}$, Pius Tshimankinda Mpiana ${ }^{4}$, Koto-te-Nyiwa Ngbolua ${ }^{2,3, *}$. \\ ${ }^{1}$ Institut Supérieur Pédagogique de Yakoma, Nord-Ubangi, République Démocratique du Congo \\ ${ }^{2}$ Department of Biology, Faculty of Science, University of Kinshasa, Kinshasa, \\ Democratic Republic of the Congo \\ ${ }^{3}$ Department of Environment, Faculty of Science, University of Gbadolite, Gbadolite, Nord Ubangi, \\ Democratic Republic of the Congo \\ ${ }^{4}$ Department of Chemistry, Faculty of Science, University of Kinshasa, Kinshasa, \\ Democratic Republic of the Congo \\ Corresponding author: Prof. Koto-te-Nyiwa Ngbolua (PhD) \\ jpngbolua@unikin.ac.cd
}

\begin{abstract}
The aim of the present study was to evaluate the Chemical composition and bioactivity of Anthocleista schweinfurthii Gilg (Gentianaceae) fruits, leaves, root bark and stem bark extracts against Sickle cell disease (SCD) and associated bacteria. The antisickling and antibacterial activities were carried out using Emmel and micro-dilution methods respectively. The results revealed that the fruits, leaves, root bark and stem bark extracts of $A$. schweinfurthii contains various secondary metabolites such as the alkaloids, saponins, total polyphenols, flavonoids, tannins, anthocyanis, leuco-anthocyanins and quinones. The ethyl acetate and methanol extracts displayed antisickling activity. While, the antibacterial activity of different plant extracts tested was weak toward tested bacterial strains $(C M I \geq 125 \mu \mathrm{g} / \mathrm{mL})$. The antibacterial activity can be improved by bio-guided fractionation of the n-hexane, ethyl acetate or methanol soluble fraction. This study provides for the first time a scientific basis for the in vitro antisickling activity of A. schweinfurthii.
\end{abstract}

Keywords : Sickle cell disease; antibacterial activity; Congo basin; great apes plant foods; zoopharmacognosy.

\section{Introduction}

Sickle cell disease (SCD) is a hemoglobinopathy which naturally occurring in black people. At the genetic level, SCD is characterized by a single base substitution in the gene encoding the human $\beta$-globin subunit and results in replacement of $\beta^{6}$ glutamic acid by valine that causes an abnormal, rigid and sickle shape in hypoxia (Girot 2003, Mpiana et al. 2010). In Democratic Republic of the Congo (DRC), surveys reported that $12 \%$ of the hospitalized children are sicklers and the annual cost of the treatment of SCD is higher than 1.000,00 USD per patient (Tshilolo et al. 2009). It is therefore necessary to develop innovative strategy for identifying new sources of antisickling agents through zoopharmacognosy. Indeed, in African tropical forests like Congo basin, Great apes (GAs) were reported as a good model for the understanding of malaria infection patho-physiology. Humans and great apes (bonobos, chimpanzees, gorillas, etc.) share a common gut anatomy. Although, some diseases that cause countless deaths in humans (like malaria) are ineffective or have minor non disturbing effects in GAs. These animals adopt a self medicative behavior when they are displaying malaria symptoms by selecting specific plants for controlling parasite infection while this one cause hemolytic anemia of human red blood cells (Ekutsu et al. 2016, Ngbolua et al. 2016a, Ngbolua et al. 2015). 
In this regards, we recently hypothesized that these plant items could therefore protect human sickle erythrocyte against hemolysis (by inhibiting the polymerization of sickle hemoglobin and radical oxygen species formation within sickle erythrocyte) as it does for Plasmodium falciparum infected erythrocytes in great apes (Ngbolua 2019a, Ngbolua et al. 2014a). So, some of such plant species occasionally ingested by GAs for their supposed medicinal properties were reported to contain natural product compounds that prevent the erythrocytes hemolysis through the inhibition of sickle erythrocyte sickling and this bioactivity was scientifically validated (Tshibangu et al. 2016, Ekutsu et al. 2016, Ngbolua et al. 2016a, Ngbolua et al. 2015).

The aim of this study is to evaluate the chemical composition and bioactivity of Anthocleista schweinfurthii Gilg. (Gentianaceae) fruits, leaves, root bark and stem bark extracts against SCD and associated bacteria, a plant species which has been selected through the animal source of knowledge (new paradigm) in order to develop new phytomedicine for SCD like Drepanoalpha (Ngbolua et al. 2019b). A. schweinfurhtii is a shrub or tree of 3 to $30 \mathrm{~m}$ high whose trunk has 8 at $70 \mathrm{~cm}$ in diameter. Leaves are wide; their length reaches $45 \mathrm{~cm}$ and width 3.5 to $18 \mathrm{~cm}$. The flowers have a white or cream color. They are long by 55 to $60 \mathrm{~cm}$.

\section{Methodology}

\subsection{Samples collection}

The plant material (Fruits, leaves, root bark ant stem bark) used in the present study was collected in the "MONASTERE L'ASSOMPTION" forest located in the Mont-Ngafula commune $\left(4^{\circ} 25^{\prime} \mathrm{S}\right.$ latitude and $14^{\circ} 09^{\prime} \mathrm{E}$ longitude). Its average altitude is $357 \mathrm{~m}$ above sea level.

\subsection{Test extract preparation}

The plant material $(1 \mathrm{~kg})$ was kept at room temperature $\left(25\right.$ to $\left.30{ }^{\circ} \mathrm{C}\right)$ for air drying (two weeks). The air-dried and powdered material $(50 \mathrm{~g})$ was extracted by repeated maceration with methanol $500 \mathrm{~mL}$ at room temperature. After filtering the methanol filtrates were pooled and evaporated to dryness under reduced pressure using a rotary evaporator to yield crude ethanolic extract. Extract was stored at $4^{\circ} \mathrm{C}$.

\subsection{Phytochemical screening and organic acid extraction}

The dried and powdered plant material (10 g) was repeatedly extracted by cold percolation with $95 \%$ methanol $(\mathrm{MeOH})$ and water $(100 \mathrm{~mL} \times 2)$ for 48 hours. Chemical screening was performed on the aqueous and organic extracts to investigate the presence of alkaloids, saponins, total polyphenols, flavonoids, tannins, anthocyanis, leuco-anthocyanins, quinones, terpenes and steroids according to standard protocol (Bruneton 1999). The organic acids were extracted as previously reported (Tshibangu et al. 2016).

\subsection{Blood and antisickling assay}

Blood samples used to evaluate the antisickling activity of the plant extracts in this study were taken from known SCD adolescent patients attending the "Centre de Médecine Mixte et d'Anémie SS" and "Centre Hospitalier Monkole", both located in Kinshasa area, D.R. Congo. None of the patients had been transfused recently with $\mathrm{Hb}$ AA blood. All antisickling experiments were carried out with freshly collected blood. In order to confirm their $S S$ nature, the above-mentioned blood samples were first characterized by hemoglobin electrophoresis on 
cellulose acetate gel, as previously reported (Ngbolua et al. 2014b). They were found to be SS blood and were then stored at $\pm 4^{\circ} \mathrm{C}$ in a refrigerator. An informed consent was obtained from all the patients participating in the study. All the research procedures have received the approval of Department of Biology Ethics Committee. Sickle cell blood was diluted with $150 \mathrm{mM}$ phosphate buffered saline $\left(\mathrm{NaH}_{2} \mathrm{PO}_{4} 30 \mathrm{mM}, \mathrm{Na}_{2} \mathrm{HPO}_{4} 120 \mathrm{mM}, \mathrm{NaCl} 150 \mathrm{mM}\right)$ and mixed with an equivalent volume of $2 \%$ sodium metabisulfite.

A drop from the mixture was spotted on a microscope slide in the presence or absence of methanol extracts and covered with a cover slip. Paraffin was applied to seal the edges of the cover completely to exclude air (Hypoxia). Duplicate analyses were run for each extract. The RBCs were analyzed by measuring various parameters including the area, perimeter and the radius of each RBC using a computer assisted image analysis system (Motic Images 2000, version 1.3; Motic Chine Group Co LTD) and statistical data analysis were processed using Microcal Origin 6.1 package software.

\subsection{Determination of Minimum inhibitory concentration (MIC)}

The antibacterial activity of $A$. schweinfurthii was assessed against selected bacteria strains by the micro-well dilution method and the minimum inhibitory concentration (MIC) values, which represent the lowest sample concentrations that completely inhibit the growth of microorganisms, were obtained using this method (Ngbolua et al. 2014c, Tshibangu et al. 2016). The $10 \mathrm{mg}$ samples (Fruits, leaves, root bark ant stem bark) were each dissolved in DMSO $(250 \mu \mathrm{L})$ and diluted with Mueller-Hinton Broth (MHB) in order to reach concentrations of $2000 \mu \mathrm{g} / \mathrm{mL}$ and a $5 \mathrm{~mL}$ solution (final volume, and 5\% DMSO final concentration). These solutions were used as stock solutions. The inoculum of microorganisms was prepared from $24 \mathrm{~h}$ old MHB cultures. The microbial suspensions were prepared by adding five colonies of each of the test bacteria to $2 \mathrm{~mL}$ of with sterile physiological solution $(0.9 \%$ $\mathrm{NaCl}$ ) and adjusted with this sterile physiological solution to match that of a $0.5 \mathrm{McFarland}$ standard solution $\left(10^{8}\right.$ cells $\left./ \mathrm{mL}\right)$. They were then diluted $(1 / 100)$ to achieve $10^{6} \mathrm{CFU} / \mathrm{mL}$. The assay was carried out using sterile clear polystyrene 96 -well microtiter plates (round bottom). The wells in the columns 2 to 8 and those in columns 11 and 12 were filled with $100 \mu \mathrm{L} \mathrm{MHB}$ (Mueller Hinton Broth). Briefly $200 \mu \mathrm{L}$ of stock solution of each A. schweinfurthii sample were added to the wells in column 1 (A1 to $\mathrm{H} 1$ ), and two-fold serial dilutions were made from column 1 to column 8 . Then $5 \mu \mathrm{L}$ of the inoculum were dispensed to all the wells except those in column 12. The wells in columns 11 and 12 we used as positive and negative controls. The negative control wells (growth control) contained MHB and bacteria suspension without test sample (column 11) and the positive control wells contained only MHB (control of MHB sterility: column 12). The microplates ( 96 wells) were incubated at $37^{\circ} \mathrm{C}$ for 24 hours. After the incubation, $5 \mu \mathrm{L}$ de colorant resazurin 1\% (7-Hydroxy-3H-phenoxazin-3-one10-oxide) were added to each well and the microplates were then incubated for 5 hours. The minimum inhibitory concentration (MIC) was determined as the lowest $A$. schweinfurthii extracts dose at which no growth were observed after 24 and 48 hours.

\section{Discussion}

The phytochemical analyses performed on A. schweinfurthii fruits, leaves, root bark and stem bark extracts revealed the presence of alkaloids, saponins, total polyphenols, flavonoids, tannins, anthocyanis, leuco-anthocyanins, quinones. The presence of various secondary metabolites in the plant could justify its medical use. Indeed, A. schweinfurthii is reported to 
treat bacterial infections (Bruneton 1999). Compounds, which are significantly present in the plant, are well known for their large spectrum of pharmacological properties, including antimicrobial (alkaloids) and antioxidant (polyphenols) activities (Ngbolua et al. 2014c).

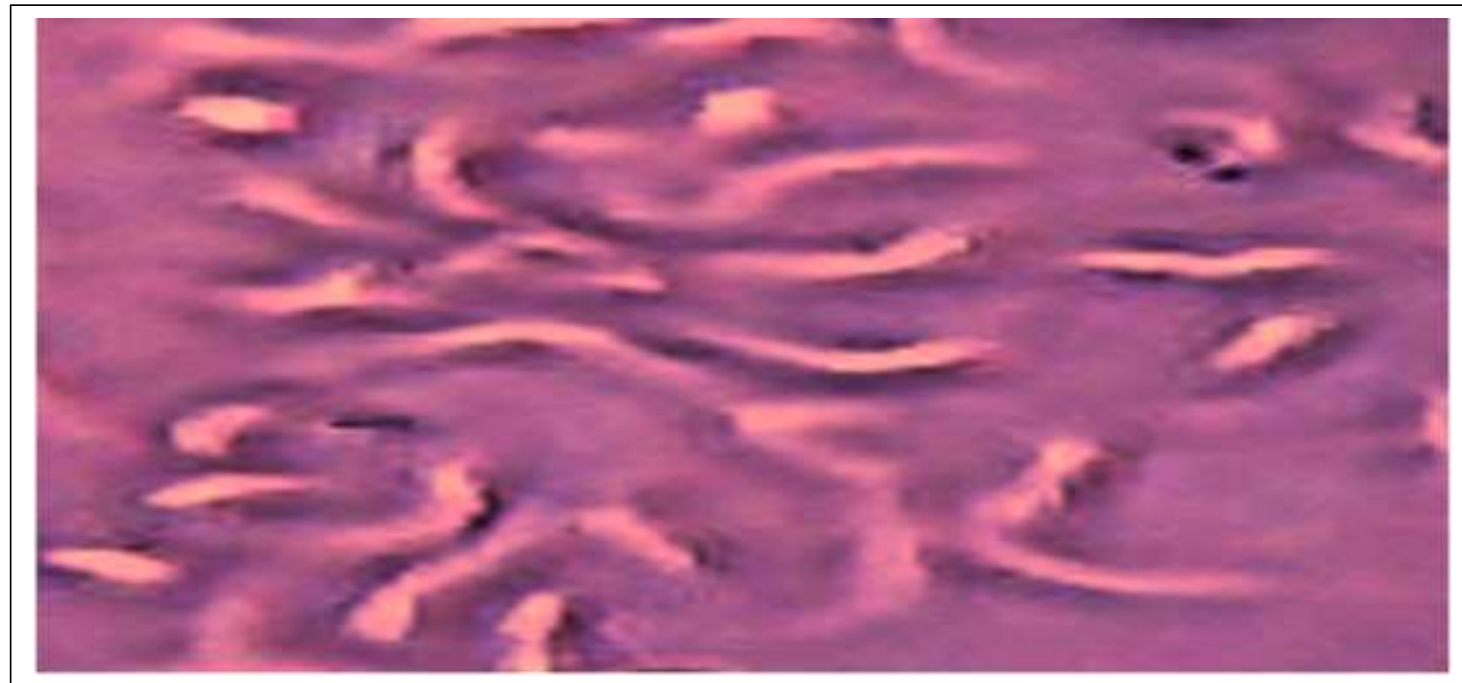

(a) Untreated SS RBCs (control)

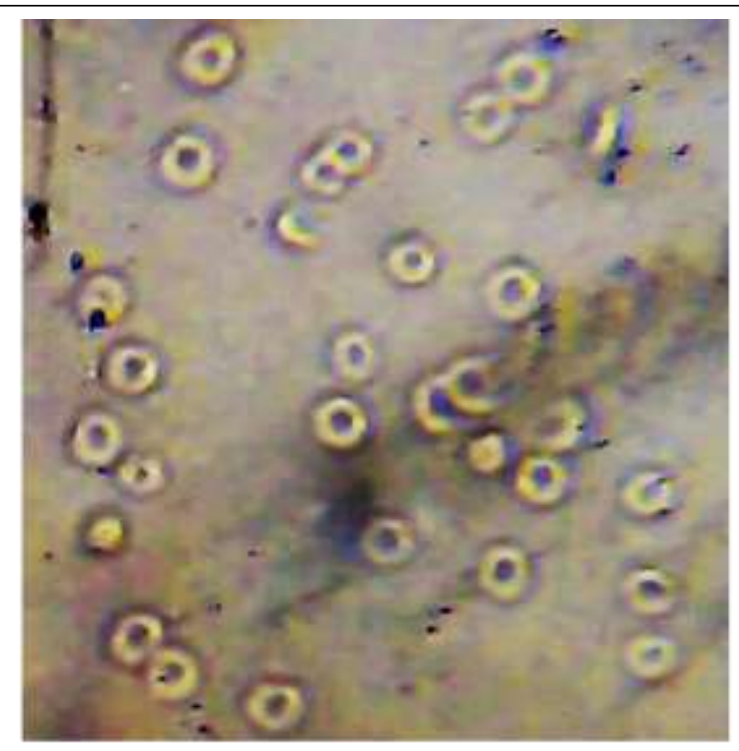

(b) SS RBCs + organic acid extract

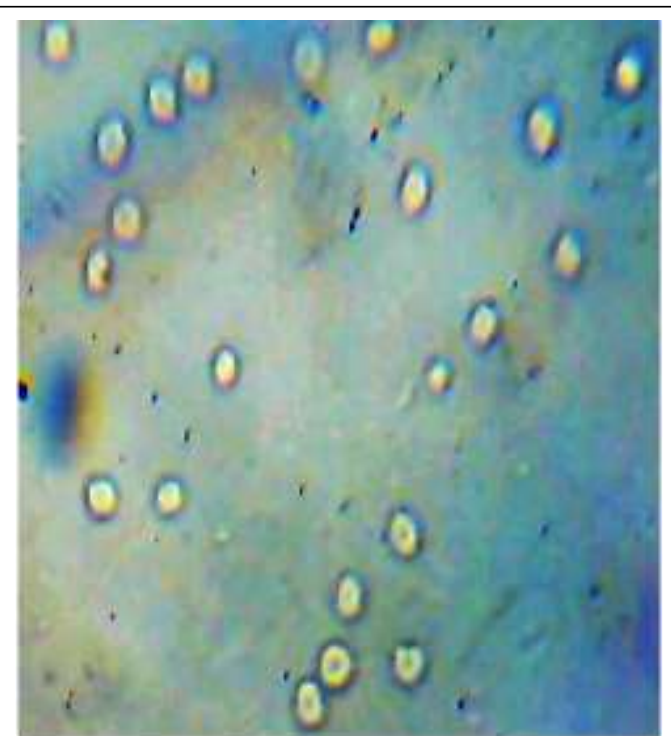

(c) $\mathrm{SS} \mathrm{RBCs}+\mathrm{MeOH}$ extract

Figure 1. Microscopy phenotype of sickle erythrocyte in different conditions $(\mathrm{NaCl} 0.9 \%$, $\mathrm{Na}_{2} \mathrm{~S}_{2} \mathrm{O}_{5} 2 \%, \mathrm{X} 500$ )

Figure 1a shows that the control contains in majority sickle-shaped erythrocytes, confirming the SS nature of the blood. Mixed together with ethyl acetate and methanol extracts of the fruits (Figure 1b, c), the majority of erythrocytes are reversed normal-shape. This indicates that $A$. schweinfurthii have antisickling effects. This activity could be due to compounds such as anthocyanins or phenolic or triterpenoic acids as previously reported 
(Tshibangu et al 2016 et Ngbolua et al 2014a). The treated SS RBCs demonstrated a remarkable similarity to normal red blood cells through the cellular parameters such as radius, area and the perimeter of RBCs. Indeed, the antisickling activity results in the resurgence of the radius (passage of the irregular shape lengthened to the circular shape), the increase of the cellular surface (from 299.5 to $314.2 \mu \mathrm{m}^{2}$ ) and the decrease of its perimeter (from 110.3 to $62.8 \mu \mathrm{m}$ ) as revealed by the results of computer analysis in table 1 .

Table 1. Average values of radius, surface and perimeter of sickle erythrocytes before and after treatment with $A$. schweinfurthii organic acids rich extract

\begin{tabular}{lccl}
\hline Paramètre mesuré & $\begin{array}{c}\text { Untreated SS RBCs } \\
\text { (Control) }\end{array}$ & Treated SS RBCs & Observation \\
Radius $(\mu \mathrm{m})$ & 0.0 & 10.0 & Reappearance \\
Surface $\left(\mu \mathrm{m}^{2}\right)$ & 299.5 & 314.2 & Increase \\
Perimeter $(\mu \mathrm{m})$ & 110.3 & 62.8 & Decrease \\
\hline
\end{tabular}

[Image size: width (460 pixels), height (435 pixels), objective lens (x100), accuracy (1), Resolution (460x345x24 bit), uncompressed size (464 kb), software package: Motic Images ver 1.3.] (In the analysis of images by this software, the normalized erythrocytes are considered as a circle while the drepanocytes have irregular geometric form).

As it can be seen in table 1, the used computer software package/program did not give the average radius for drepanocytes, as sickled cells of untreated SS blood are not circular. The average radius appeared after treatment of SS RBCs by plant extract (organic acids rich extract, $50 \mu \mathrm{g} / \mathrm{mL}$ ), conduct into the re-appearance of the biconcave form of RBCs by reducing the perimeter of sickle RBCs and increasing their surface $(\mathrm{p}<0.05)$.

Due to the high cost of modern therapy for SCD, a medicinal plant species displaying at the same time antisickling and antibacterial activities could be useful in the management of this disease. The antibacterial activity of $A$. schweinfurthii fruits extract was evaluated against E. coli and $S$. aureus strains. The n-hexane, ethyle acetate and methanol extracts are exhibited moderate antibacterial activity against Escherichia coli and Staphylococcus aureus with MIC values of $125 \mu \mathrm{g} / \mathrm{mL}$ and the n-hexane extract showed a weak antibacterial activity against Escherichia coli with MIC values of $500 \mu \mathrm{g} / \mathrm{mL}$.

This antibacterial activity is however weak if compared to the MIC reference value of $100 \mu \mathrm{g} / \mathrm{mL}$. Indeed, a value lower or equal to 100 indicates a great antibacterial activity. The difference in the bioactivity would be due to the nature of the bacterial wall (Tshibangu et al. 2016).

These results are in agreement with previous works on the antimicrobial activity of natural products of plant origin. It was reported that $S$. aureus and $E$ coli constitute both the principal bacteria responsible for septicemia and the osteomyelitis in SCD patients (Diagne et al. 2003). To this end, A. schweinfurthii is a better candidate for the development of 
phytomedicine with broad spectrum of action for the management of SCD. These results corroborate former work on the antimicrobial properties of the secondary metabolites of plant origin (Ngbolua et al. 2016b). It is well established that $S$. aureus and E coli constitute the principal bacteria responsible for septicemia and the osteomyelitis in SCD patients (Diagne et al. 2003). To this end, a plant species displaying at the same time antibacterial and antisickling activities is a better candidate for the development of phytomedicine with broad spectrum of action for the management of SCD. The weak antibacterial activity observed in this study can be improved by bio-guided fractionation of the ethyl acetate or methanol soluble fraction. To our knowledge, it is for the first time that the antisickling activity A. schweinfurthii is reported in the literature.

\section{Conclusion}

The present study evaluated the chemical composition and the antisickling and antibacterial activities of $A$. schweinfurthii. The results revealed that:

- The fruits of A. schweinfurthii contains various secondary metabolites such as the anthocyanins, flavonoids, tannins, quinones, saponins, alkaloids, steroids, terpenoids and leuco-anthocyanins ;

- All tested extracts displayed interesting antisickling activity. Organic acid extract revealed the most interesting antisickling activity in vitro ;

- The antibacterial activity of the plant extracts was weak toward tested bacterial strains $(\mathrm{CMI}>125 \mu \mathrm{g} / \mathrm{mL}$ ).

This study provided experimental evidence that supports further development of $A$. schweinfurthii extracts as a medicine for the management of SCD in endemic areas.

\section{References}

Bruneton J. 1999. Pharmacognosie, Phytochimie des Plantes Médicinales. 3rd Edition, Revue et Augmentée, Tec \& Doc, Paris.

Diagne I, Diagne-Gueye ND, Signate-Sy H, Camara B, Lopez-Sall P, Diack-Mbaye A. 2003. Mana-gement of children with sickle cell disease in Afric : experience in a cohort of children at the Royal Albert Hospital in Dakar. Médecine Tropicale 63(4-5) : 513-520.

Ekutsu GE, Ngbolua KN, Bolaa MB, Mpiana PT, Ngoy BP, Masengo AC, Bongo GN, 2016. Enquête sur la pharmacopée des bonobos (Pan paniscus, Primates) dans un foyer endémique et Mise en évidence de l'activité anti-drépanocytaire chez un taxon végétal (Treculia africana Decne ex Trécul, Moraceae) testé in vitro. International Journal of Innovation and Applied Studies 14(2): 315-326.

Girot R, Begué P, Galacteros F. 2003. La drépanocytose. Editions Jofn LIBBEY Eurotext, Paris: France.

Mpiana PT, Ngbolua KN, Bokota MT, Kasonga TK, Atibu EK, Mudogo V. 2010. In vitro Effects of Anthocyanins Extracts From Justicia secunda VAHL on the Solubility of Hemoglobin Sand Membrane stability of Sickle Erytrocytes, Blood Transfusion 8 :248254.

Mpiana PT, Tshibangu DST, Shetonde OM, Ngbolua KN. 2007. In vitro antidrepanocytary activity (anti-sickle cell anaemia) of some Congolese plants. Phytomedicine 14 :192-195. 
Ngbolua KN, Bongo GN, Masengo CA, Djolu RD, Mpiana PT, Mudogo M et al. 2014a. Ethnobotanical survey and Ecological study of Plants resources used in Folk medicine to treat symptoms of Tuberculosis in Kinshasa City, Democratic Republic of the Congo. J. of Modern Drug Discovery and Drug Delivery Research, V1I3. DOI: 10.15297/JMDDR.V1I4.01,

Ngbolua KN, Bishola TT, Mpiana PT, Mudogo V, Tshibangu DST, Ngombe KN, Ekutsu EG, Gbolo BZ, Kabena NO. 2014b. Ethno-pharmacological survey, in vitro antisickling and free radical scavenging activities of Carapa procera DC. stem bark (Meliaceae). Nova J. Med. \& Biol. Sci., 2 (2): 01-14.

Ngbolua KN, Mubindukila NR, Mpiana PT, Masengo CA, Baholy R, Fatiany PR, Ekutsu GE, Gbolo BZ. 2014c. In vitro Assessment of Antibacterial and Antioxidant activities of a Congolese medicinal plant species Anthocleista schweinfurthii Gilg (Gentianaceae). J. Mod. Drug Discov. \& Drug Deliv. Res. V1I3. DOI: 10.15297/JMDDR.V1I3.03.

Ngbolua KN, Bolaa BM, Mpiana PT, Ekutsu EG, Masengo AC, Tshibangu DST, Mudogo V, Tshilanda DD, Kowozogono KR. 2015. Great Apes Plant Foods As Valuable Alternative Of Traditional Medicine In Congo Basin: The Case Of Non-Human Primate Bonobos (Panpaniscus) Diet at Lomako Fauna Reserve, Democratic Republic of the Congo. J. of Advanced Botany and Zoology, V3I1, http://www.scienceq.org/archive user.php?jname=abz\#.VgY6un3szoA.

Ngbolua KN, Mpiana PT, Tshibangu DST, Gbolo ZB. 2016a. Bioactivity of Medicinal Plants Traditionally Used for the Management of Sickle cell disease in Democratic Republic of the Congo : State of the Art and Future Directions. In: Sickle Cell Disease: Genetics, Management and Prognosis. NOVA PUBLISHERS, New York, USA, pp: 7994.

Ngbolua KN, Mpiana PT, Mwanza BF, Tshibangu DST, Tshilanda DD, Masengo AC, Mudogo V, Baholy R, Fatiany PR. 2016b. Antisickling and antibacterial activities of Garcinia punctata Oliv. (Clusiaceae) and Tetradenia riparia (Hochst.) Codd (Lamiaceae) from Democratic Republic of the Congo. J. Adv. Med. \& Life Sci. V4I1. DOI: 10.15297/JALS.V4I1.01.

Ngbolua KN. 2019a. Evaluation de l'activité anti-drépanocytaire et antipaludique de quelques taxons végétaux de la République démocratique du Congo et de Madagascar. Editions Universitaires Européennes, Riga : Latvia. ISBN : 978-613-8-46359-7.

Ngbolua KN, Mpiana PT, Mudogo V. 2019b. Études chimique et pharmacologique de Drepanoalpha: Puissant complément alimentaire anti-drépanocytaire développé en République démocratique du Congo. Editions Universitaires Européennes, Riga : Latvia. ISBN : 978-613-8-46436-5.

Tshibangu DST, Ngbolua KN, Lengbiye EM, Dorothée D, Bienvenu MM, Jeff BI, Blaise MM, Virima M, Pius TM. 2016. Chemical composition and bioactivity of Canarium schweinfurthii stem bark extracts from DR Congo against Sickle cell disease and associated bacteria. Journal of Pharmacognosy and Phytochemistry, 5(4): 181-18.

Tshilolo L, Aissi LM, Lukusa D, Kinsiama C, Wembonyama S ; Gulbis B, Vertongen F. 2009. Neonatal screening for sickle cell anaemia in the Democratic Republic of Congo: experience from a pioneer project on 31204 newborns. Journal of Clinical Pathology 62:35-38. 